\title{
GROSS DOMESTIC SAVINGS AND GROSS CAPITAL: WHAT MATTERS TO THEIR FORMATION IN AN ERA OF ECONOMIC RECESSION IN NIGERIA?
}

\author{
Success Abusomwan ${ }^{1 *}$, Jessy Ezebuihe ${ }^{2}$ \\ ${ }^{1}$ Department of Economics and Statistics, Faculty of Social Sciences, University of Benin, \\ Benin City, Edo State, Nigeria \\ ${ }^{2}$ Department of Economics, University of Nigeria, Nsukka, Enugu State, Nigeria \\ osamede.abusomwan@uniben.edu \\ jessyezebuihe@gmail.com
}

\begin{abstract}
The objective of this study is to empirically investigate the long run and short run dynamic impact of interest rate and output on gross domestic savings and gross capital formation in Nigeria. Literatures, both theoretical and empirical, suggest that the rate of interest and output are the key factors influencing savings and investments. A review of factors influencing interest rates and output in Nigeria is necessitated by the recent economic downturns in Nigeria that has resulted in tight monetary policy which some commentators regard as inimical to growth. Employing Ordinary Least Squares, Co-integration, Error Correction Mechanism and Granger Causality econometric techniques on a data spanning 1981 to 2014 of the Nigerian economy sourced from the World Development Index, it was found that changes in output explains the long run and short run dynamic behaviour of gross domestic savings and gross capital formation which were used as proxies for savings and investment respectively. Whereas, a bi-causality was established between output and investment, causality flowed from output to savings in Nigeria. The research also found that interest rate is not a significant determinant of savings and investment in Nigeria in both long run and short run. It is therefore recommended that to enhance investment in a period of economic downturn in Nigeria, aggregate demand should be boosted to enhance output through vigorous pursuit of fiscal policy while implementing contractionary monetary policy to address inflationary pressures created by the increase in demand. Domestic savings will improve and gross capital formation will be sustained.
\end{abstract}

Keywords: Gross Capital Formation, Gross Domestic Savings, Error Correction Model.

JEL classification: A1; C22; E10.

\section{Introduction}

Savings and investment have been described as very important in enhancing the level of growth especially of developing economies. The importance of these variables for economic development warrants a persistent and cursory research on its determinants in a dynamic world. A study of the core determinants of these variables is therefore important. In economic theory, these determinants are output and the rate of interest (lyoha, 2007). Interest rate is defined as the price of capital that equilibrates desired savings and investment in the long run (Anyanwu, 1993). In national income accounting, a key component of output is investment (lyoha, Oyefusi and Oriakhi, 2003). The accelerator principle of investment explains that the core determinant of investment in changes in output (Appienti, Ofori and Damptey, 2016). To Nkah (1997), savings is seen as the amount of income per time that is not consumed by economic units. Domestic savings is an important

\footnotetext{
* Corresponding Author: Success Abusomwan
} 
component of a country's total savings and includes government or public sector savings and private domestic savings (Okere and Ndugbu, 2015). Investment is the creation of net additions to the stock of physical capital necessary for growth (lyoha et al, 2003). Keynes (1936) in his liquidity preference theory established the relationship between interest rate, savings and investment. According to him, at higher interest rate, people would prefer to hold their wealth in the form of interest bearing assets. One of these assets is the savings account in financial institutions. An increase in interest rate therefore is expected to stimulate savings mobilization thereby enhancing the availability of investible funds and ultimately economic growth. This however is dependent on the strength and level of development of the financial system in an economy (McKinnon, 1973). For most developing economies like Nigeria, characterised by weak financial sector and the continuous growth of general prices of goods and services, people prefer to leave their monies outside the banking system. Therefore, Acha and Acha (2011) posited that saving may not be responsive to interest rates due to lack of confidence in the banking system, low income and preference for cash in developing countries like Nigeria. The Nigerian financial system was deregulated in the second half of 1980 s so as to increase savings and its corresponding investment to achieve economic growth. This notwithstanding, the Nigerian economy has continued to experience low levels of economic growth and the aggregate supply of loanable fund has continued to diminish due to growing inflation rate (Olayemi and Michael, 2013). Recently, there have been policies by the monetary and fiscal authorities in Nigeria aimed at stabilising the economy and bringing it back to the path of growth. These policies directly or indirectly affect the rate of interest and output. In July 2016, the Central Bank of Nigeria (CBN) increased the monetary policy rate by 200 basis points to 14 percent from 12 percent. This was necessitated by the high level of inflation and a dwindling currency. There have been different reactions about the effects of these policies on the overall economy by stakeholders and economic commentators but there hasn't been to the best of the researcher's knowledge any recent work simultaneously $x$-raying the long run and short run dynamic responsiveness of investments and savings to the changes in interest rate and output which are the intermediate and ultimate targets of these policies respectively. This is the gap this research intends to fill.

The objective of this study is to investigate the long run and short run dynamic relationship between interest rate and output on gross domestic savings and gross capital formation in Nigeria. This work therefore hypothesises the significant impact of interest rate and income on investment in both short run and long run on one hand and the significant impact of interest rate and income on savings in both short run and long run on the other hand. The first section of this research work introduces the research. Review of related literature on the subject matter of interest is carried out in section two. Section three entails methodology and models employed by the study. The presentation and analysis of empirical results is in section four while the last section deals with summary of findings, policy implications and recommendations.

\section{Review of related literature}

Researchers in various fields have empirically investigated the relationships between income, interest rates, savings and investment. Their works are discussed in section 2.1 below. In section 2.2, brief theoretical underpinnings for this research will be considered.

\subsection{Empirical review}

Adelakun (2015), in an investigation of the determinants of savings and investment in Nigeria, found that only income (GDP) has significant impact on savings and that it is the main factor influencing both savings and investment in Nigeria. Uche (2012) investigated the effect of interest rate on savings and investment in Nigeria using the multiple regression 
model and found that it has a positive significant impact on aggregate saving and a negative significant impact on aggregate investment in Nigeria. Jain and Baliyan (2014) in an extensive empirical review of literatures found economic growth (output) to be a main driver of both savings and investments in India. Larsen (2004), in a study of the effect of mortgage interest rate on real estate investment in the United States of America found that low mortgage interest rate make direct real estate investment attractive to the suppliers of real estate units. Bader and Malawi (2010) investigated the impact of interest rate on investment in Jordan over the period of 1990-2005 using the Johansen Cointegration test technique. They found that interest rate has a negative impact on investment. Bayai and Nyangara (2013) utilising multiple regression analysis, found investment to be positively affected by income but negatively affected by the rate of interest in Zimbabwe. Appienyi, Ofori and Damptey (2016) in a research of the key determinants of investment in Ghana, employing co-integration and causality tests found a bi-causal relationship between investment and output. A uni-causal effect was however found to flow from interest rate to investment. Employing Error Correction mechanism (ECM) and Ordinary Least Squares (OLS) techniques to investigate the dynamic short run and long run determinants of private investment in Argentina, Acosta and Loza (2005) found that only shocks in returns and aggregate demand explained short run variation in investment whereas development of the capital and credit markets and fiscal sustainability determined investments in the long run. Linus (2013) did not find interest rate as a determinant of investment in Nigeria in the long run using OLS regression technique. Adopting both OLS and ECM regression techniques, Duruechi and Ojiegbe (2015) did not find any significant relationship between interest rate and investment in Nigeria from 1990 to 2013. From the review above, output is found to be a main determinant of investment. However, there is conflicting results about the effect of interest rate on investment.

Nasir and Khalid (2004) employing multiple regression technique found that GDP growth rate positively and significantly affect savings. They also observed that savings was insensitive to the rate of interest in Pakistan. Olayemi and Michael (2013) assessed the impact of real interest rate on savings mobilization in Nigeria using the Vector Auto Regression (VAR) technique and time series data spanning from 1980-2008. The study revealed that interest rate has negatively impacted savings mobilization in Nigeria. Udude (2015) examined the impact interest rate has on savings in the Nigerian economy from 1981 to 2013 adopting the VAR technique. Results showed that a 1 percent increase in a period lagged interest rate on deposit, on the average will cause a $0.1 \%$ increase in savings. Epaphra (2014) empirically investigated the determinants of Tanzania's national savings using OLS, Co-integration and Error Correction Model techniques. He found that economic growth granger causes national savings and not the other way round. According to the findings of Ogbokor and Samahiya (2014) in a time series analysis of the determinants of savings in Namibia and employing ECM and Co-integration techniques, whereas income and inflation rate significantly enhances savings, interest rate is not significant in explaining savings in Namibia. Again, from the review above, a positive and significant relationship is found between income and savings most of the time but this cannot be confirmed for the relationship between interest rate and savings.

\subsection{Theoretical considerations}

To the classicals, at any particular level of income, the amount saved will increase with any rise in the rate of interest (Okere and Ndugbu, 2015). McKinnon (1973) and Shaw (1973) substantiated this by opining that for an economy that is developing, there exist a positive relationship between interest rate and savings. This is no doubt intuitively appealing since a greater part of savings by household, in a developing economy characterised by inefficient market for stocks and bonds is made up of cash balances and quasi-monetary assets. Keynes (1936) identified the major determinant of investment and savings as the country's 
national income. According to him, the higher the income level, the higher the level of saving and investment. The accelerator theory states that investment is a function of change in output. McKinnon (1973) and Shaw (1973) both in their financial liberalization model postulated when financially repressed developing countries characterized by interest rate ceilings embrace financial liberalization, savings will improve. Increased savings will enhance the supply of credits, improve investments and ultimately stimulate economic growth.

\subsection{Gross Capital Formation and Gross Domestic Savings in Nigeria}

Gross Capital formation (GCF) is used as a proxy for investment in this study. GCF of Nigeria has not been impressive compared to the regional statistics. The index of investment decreased from an average figure of USD10.13billion in the period 1981-1985 to USD2.74billion in the period 1986-1990. Although there had been records of growth of GCF to USD75.51billion in the period 2011-2014, it still fell below the averages of Lower Middle Income (LMI) countries and Sub-Saharan African (SSA) countries of USD338.21billion and USD1507.51billion respectively in the same period. This is revealed in Figure 1 below.

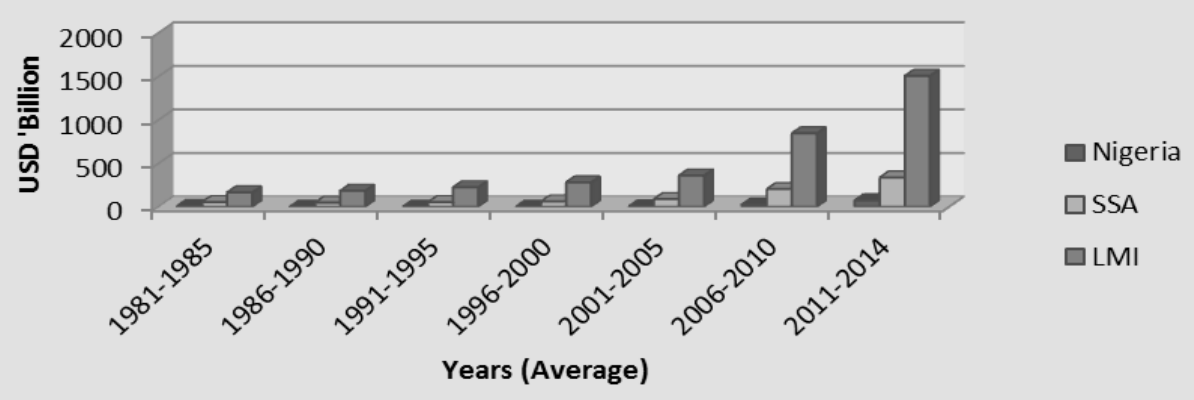

Figure 1: Gross Capital formation in Nigeria, SSA and LMI

Source: Author, using data from WDI (2016)

Figure 2 is a reflection of the figure above. Gross domestic savings is least in Nigeria compared to SSA and LMI. From an average value of USD10.54billion in the period 1981-1995, it declined to USD7.17 billion in 1996-2000. It has increased since then to USD121.99billion. However, it was behind the GDS statistics of SSA and LMI average figures.

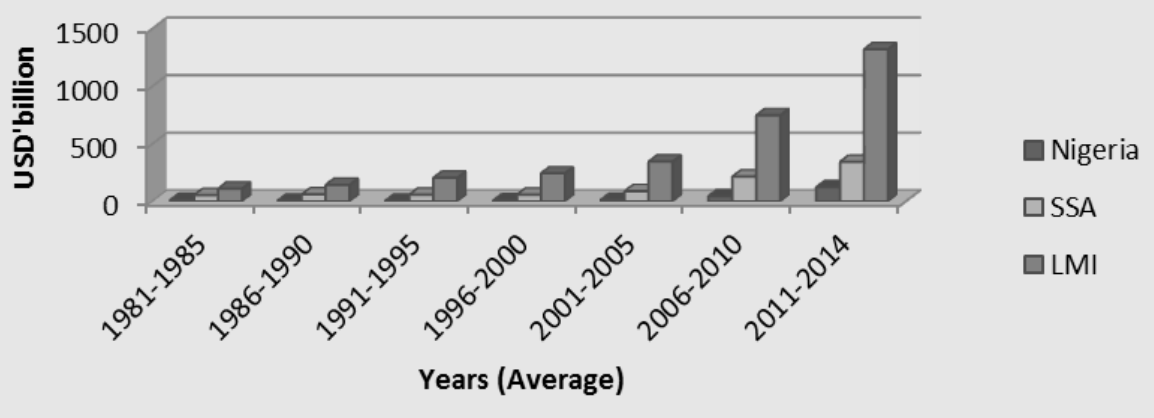

Figure 2: Gross Domestic Capital in Nigeria, SSA and LMI

Source: Author, using data from WDI (2016) 


\section{Methodology and the models}

This work adopts the OLS and ECM estimation techniques to analyze the time series data of GCF, GDS, GDP, Prime lending rate and inflation rate, spanning 1980 to 2014 in Nigeria. The data was obtained from World Development Index (WDI). The unit root and cointegration pre-estimation tests are carried out to test for stationarity and the existence of long run relationship between the variables respectively. Two models are specified in this research. The first is the model that explains the relationship between GDP, PLR, INFL and Gross Capital formation while the second model explains the relationship between GDP, $P L R$, INFL and Gross Domestic savings. For each model, the specifications of the OLS and ECM models are presented below.

\subsection{The OLS model specification of Model 1}

$$
L G C F=\alpha+\beta_{1} L G D P+\beta_{2} L P L R+\beta_{3} L I N F L+\mu
$$

LGCF represents the natural log of Gross Capital Formation and is the explained variable, a proxy for investment in Nigeria. LGDP is the natural log of GDP, a proxy for output in Nigeria. $L P L R$ is the natural log of prime lending rate and captures interest rate while LINFL is the natural log of inflation in Nigeria. $\alpha$ is the constant term while $\beta_{1}, \beta_{2}$ and $\beta_{3}$ are the coefficients of the explanatory variables. $\mu$ is the stochastic error term. It is expected from economic theory that $\beta_{1}$ is positive while $\beta_{2}$ and $\beta_{3}$ are negative.

\subsection{The Error Correction Model specification of Model 1}

$$
\Delta L G C F=\alpha_{t}+\beta_{t 1} \Delta L G D P+\beta_{t 2} \Delta L P L R+\beta_{t 3} \Delta L I N F L+\eta e c m(-1)+\mu_{t}
$$

$\Delta$ is lag operator, $\operatorname{ecm}(-1)$ is one period lag of the residual from equation 1 . It is the equilibrating factor. $\alpha_{t}$ is the constant term, $\beta_{t 1}, \beta_{t 2}$ and $\beta_{t 3}$ are the coefficients of one period lagged log of explanatory variables (LGDP, LPLR, LINFL). $\eta$ is the coefficient of the one period lagged residual and $\mu_{t}$ is the error term. It is expected from economic theory that $\beta_{t 1}$ is positive while $\beta_{t 2}$ and $\beta_{t 3}$ are negative. $\eta$ is expected to be significant and negative.

\subsection{The OLS model specification of the Model 2}

$$
L G D S=\tau+\delta_{1} L G D P+\delta_{2} L P L R+\delta_{3} L I N F L+\ell
$$

LGDS is the log of Gross Domestic Savings, the explained variable which is proxy for savings in Nigeria. LGDP is the natural log of GDP which represents output in Nigeria. LPLR is the natural log of prime lending rate and $L I N F L$ is the log of inflation in Nigeria. $\tau$ is the constant term while $\delta_{1}, \delta_{2}$ and $\delta_{3}$ are the coefficients of the explanatory variables (LGDP LPLR LINFL) respectively. $\ell$ is the stochastic error term. $\delta_{1}$ and $\delta_{2}$ are expected to be greater than zero while $\delta_{3}$ is expected to be less than zero from empirical literature and economic theory.

\subsection{The Error Correction Model specification of Model 2}

$$
\Delta L G D S=\tau_{t}+\delta_{t 1} \Delta L G D P+\delta_{t 2} \Delta L P L R+\delta_{t 3} \Delta L I N F L+\theta e c m(-1)+\ell_{t}
$$


$\Delta$ is lag operator, ecm $(-1)$ is one period lag of the residual from equation 3. $\tau_{\mathrm{t}}$ is the constant term, $\delta_{t 1}, \delta_{t 2}$ and $\delta_{t 3}$ are the coefficients of the one period lagged log $\triangle L G D P$, $\triangle L P L R$ and $\triangle L I N F L$. $\Theta$ is the coefficient of the one period lagged residual while $\ell$ is the error term. $\delta_{1}$ and $\delta_{2}$ are expected to be greater than zero while $\delta_{3}$ is expected to be less than zero from empirical literature and economic theory. Also, $\Theta$ is expected to be negative and significant.

\section{Empirical results}

Table 1: Augmented Dickey Fuller Unit Root test of variables

\begin{tabular}{|c|c|c|c|}
\hline Variable & Intercept only & Intercept \& Trend & Remark \\
\hline LGCF & -4.007 & -5.175 & $\mathrm{I}(1)$ \\
\hline & $(-3.654)$ & $(-4.273)$ & \\
\hline LGDS & -8.011 & -5.406 & $\mathrm{I}(1)$ \\
\hline & $(-3.654)$ & $(-4.297)$ & \\
\hline LGDP & -5.298 & -6.668 & $\mathrm{I}(1)$ \\
\hline & $(-3.654)$ & $(-4.273)$ & \\
\hline LPLR & -4.179 & -4.574 & $\mathrm{I}(1)$ \\
\hline & $(-3.662)$ & $(-4.285)$ & \\
\hline LINFL & -5.658 & -5.599 & $\mathrm{I}(1)$ \\
\hline & $(-3.654)$ & $(-4.273)$ & \\
\hline
\end{tabular}

Source: Author's computation using e-views 7.0

Figure in parenthesis are the critical values at $1 \%$ significance

The unit root test result of the variables is presented in table 1 above. The result reveals that all the variables (LGCF, LGDS, LGDP, LPLR and LINFL) are stationary after first differencing. This implies that they are integrated of order one [I(1)].

Table 2: Ordinary Least Squares Regression result of Model 1

\begin{tabular}{|c|c|c|c|}
\hline Variable & Coefficient & t-statistics & Probability \\
\hline C & -3.954 & -1.301 & 0.204 \\
\hline LGDP & -1.05 & 9.68 & 0.000 \\
\hline LPLR & 0.236 & 0.839 & 0.409 \\
\hline LINF & -0.106 & -1.822 & 0.079 \\
\hline R-squared & 0.973 & & \\
\hline F-stat & 248.49 & & \\
\hline D-W stat & 1.95 & & \\
\hline
\end{tabular}

Source: Author's computation using e-views 7.0.

Table 2 shows the Ordinary Least Squares result of the relationship between LGCF, LGDP, LPLR and INFL in Nigeria. It explains the long run relationship between the explanatory variables and LGCF. The result shows some robustness. With $R^{2}$ value of $0.973,97.3 \%$ variation in the dependent variable is explained by the model. The F-stat value of 248.49 implies that taken together, all the explanatory variables (LGDP, LPLR and LINF) are significant in explaining variations in LGCF. The D-W statistic of 1.95 reflects an absence of first order serial correlation. These statistics makes the reliance on the results of the OLS possible. LGDP is significant in explaining changes in LGCF. The t-statistic of 9.68 clearly affirms this significance at the 1 percent level. This is also buttressed by the probability value of 0.000 . From the table, the coefficient of LGDP has a value of 1.05 implying that a 
percentage increase in Gross Domestic Product will result in 1.05 percent increase in Gross Capital Formation in Nigeria. Inflation significantly affects GCF at the 10 percent level. An increase in inflation in by 1 percent will result in a 0.1 percent decline in GCF. Prime lending rate did not show any significant relationship with GCF although with a positive co-efficient. This is evident in its t-statistic of 0.839 and probability of 0.4088 .

Table 3: Engle and Granger Co-integration result of Model 1

\begin{tabular}{|l|l|l|l|l|}
\hline Variable & ADF Lag & ADF Test Statistic & $\mathbf{9 9 \%}$ Critical ADF & Remark \\
\hline Residuals & 0 & -5.377 & -3.654 & Stationary \\
\hline
\end{tabular}

Source: Author's computation using e-views 7.0.

The Engle and Granger Co-integration result shown in table 3 above satisfactorily reveals that the residuals of the OLS results in table 2 above does not have a unit root and hence stationary at levels at the 1 percent level of significance. This is evident by the ADF test statistic of -5.377 which is above the 99 percent ADF critical value of -3.654 . The implication of this is that a long run relationship actually exists between gross domestic product, inflation, prime lending rate and gross capital formation in Nigeria. This further confirms the OLS result. The Error Correction model stated in table 4 below shows the short run dynamic behavior of LGCF. The robustness of the model is reflected by the coefficient of determination of 72.87 percent, the F-statistic of 11.19 and the D-W statistic of 1.85 , implying that 72.87 percent of the systematic variation in LGCF is explained by the model, all the variables together significantly explain this variation in the absence of autocorrelation in the short run respectively. From the result, LGDP significantly explains variation in LGCF in the short run. This is evident in the t-statistic and probability of 5.635 and 0.000 respectively at the 1 percent level. A one period lagged LGDP also significantly influence LGCF at the 5 percent level. LINFL significantly affect LGCF at the 10 percent level with t-statistic of -1.887 and 0.071 respectively. LPLR did not show any significant relationship with LGCF in the short run. This is evident in its t-statistic of 1.454 and probability of 0.158 respectively. The coefficient of the error correction term $[\operatorname{ECM}(-1)]$ with t-statistic and probabilities of -2.854 and 0.009 respectively is significant at the 1 percent level. It is also negative as expected. With a coefficient of $109 \%$ it however reveals an overshooting in the next period in the event of dis-equilibrium in the current period.

Table 4: Error Correction Model result of Model 1

\begin{tabular}{|c|c|c|c|}
\hline Variable & Coefficient & t-statistics & Probability \\
\hline C & -0.0005 & -0.011 & 0.991 \\
\hline DLGDP & 0.8972 & 5.635 & 0.000 \\
\hline DLPLR & 0.3864 & 1.454 & 0.158 \\
\hline DLINF & -0.1021 & -1.887 & 0.071 \\
\hline DLGDP(-1) & -0.8817 & -2.146 & 0.041 \\
\hline ECM(-1) & -1.0986 & -2.854 & 0.009 \\
\hline R-squared & 0.7287 & & \\
\hline F-stat & 11.1919 & & \\
\hline D-W stat & 1.8597 & & \\
\hline
\end{tabular}

Source: Author's computation using e-views 7.0.

Table 5 shows the long run relationship between gross domestic savings, gross domestic product, prime lending rate and inflation in Nigeria employing the ordinary least squares regression technique. The coefficient of determination reflects goodness of fit of the model. With a value of 0.994 , it implies that 99.4 percent of the systematic variation in LGDS is explained by the model. The F-statistics is significant at the 1 percent level nullifying the 
hypothesis that taken together, the variables in the model (LGDP, LPLR and LINFL) do not significantly influence LGDS. The t-statistics and probability reveals that LGDP, LINF and LPLR are significant in determining LGDS at the 1 percent, 5 percent and 10 percent levels respectively. With a t-statistics of 11.623 and probability of 0.001 and coefficient of 1.64 , a percentage change in GDP will significantly result in a 1.64 percent change in gross domestic savings in Nigeria at the 1 percent significant level. This confirms a positive relationship between output and savings in Nigeria. A percentage increase in interest rate (PLR) will also increase savings by 4.25 percent although at the 10 percent level of significance. This implies that the savings behaviour of Nigerians is less likely to be affected by interest rates in the long run.

Table 5: Ordinary Least Squares Regression result of Model 2

\begin{tabular}{|c|c|c|c|}
\hline Variable & Coefficient & t-statistics & Probability \\
\hline C & -31.594 & -3.853 & 0.031 \\
\hline LGDP & 1.640 & 11.623 & 0.001 \\
\hline LPLR & 4.257 & 2.502 & 0.088 \\
\hline LINF & 1.201 & 3.723 & 0.034 \\
\hline R-squared & 0.994 & & \\
\hline F-stat & 97.94 & & \\
\hline D-W stat & 1.32 & & \\
\hline
\end{tabular}

Source: Author's computation using e-views 7.0.

Surprisingly, inflation, with a t-statistic of 3.723 also positively enhances savings in Nigeria at the 5 percent level of significance. This negates a-priori expectation. This may be explained by aversion of Nigerians to spending during periods of rising prices which could stir up output downturns.

Table 6: Engle and Granger Co-integration result of Model 2

\begin{tabular}{|l|l|l|l|l|}
\hline Variable & ADF Lag & ADF Test Statistic & $\mathbf{9 9 \%}$ Critical ADF & Remark \\
\hline Residuals & 0 & -3.654 & -5.571 & Stationary \\
\hline
\end{tabular}

Source: Author's computation using e-views 7.0.

The Engle and Granger co-integration result presented above confirms the long run co-integrating relationship between LGDS, LGDP, LPLR and LINFL in Nigeria. The Augmented Dickey Fuller 99 percent critical value of -5.571 is greater that the test statistic of -3.654 of the unit root test of the residuals implying that at the 1percent significance level, the variables in the model are co-integrated.

Table 7: Error Correction Model result of Model 2

\begin{tabular}{|c|c|c|c|}
\hline Variable & Coefficient & t-statistics & Probability \\
\hline C & -0.042 & -0.403 & 0.690 \\
\hline DLGDP & 1.355 & 2.847 & 0.009 \\
\hline DLPLR & 0.530 & 0.790 & 0.437 \\
\hline DLINF & -0.011 & -0.070 & 0.945 \\
\hline ECM(-1) & -0.762 & -3.680 & 0.001 \\
\hline R-squared & 0.624 & & \\
\hline F-stat & 8.618 & & \\
\hline D-W stat & 2.149 & & \\
\hline
\end{tabular}

Source: Author's computation using e-views 7.0. 
From the results of the Error Correction Model presented in Table 7 above, the error correction term is correctly negatively signed and significant. This enhances the reliability of the ECM result. With a coefficient of -0.762 , it shows that 76.20 percent of the disequilibrium in the current period will be corrected in the next period. The result also reveals that the short run dynamic behaviour of LGDS is significantly explained by LGDP. A percentage increase in output (LGDP) in the short run will lead to 1.35 percent increase in savings (LGDS). Though not significant, LPLR and LINF positively and negatively influence LGDS in the short run respectively.

Table 8: Granger Causality test results

\begin{tabular}{|l|c|c|c|c|}
\hline Null Hypothesis: & F-statistic & Probability & Decision & Causality \\
\hline LGDP does not Granger Cause LGCF & 10.54 & 0.000 & Reject & \multirow{2}{*}{ Feedback } \\
LGCF does not Granger Cause LGDP & 3.704 & 0.038 & Reject & \\
\hline LGDP does not Granger Cause LGDS & 6.621 & 0.005 & Reject & \multirow{2}{*}{ Uni-directional } \\
LGDS does not Granger Cause LGDP & 1.539 & 0.233 & Accept & \\
\hline LPLR does not Granger Cause LGCF & 1.003 & 0.380 & Reject & \multirow{2}{*}{ No Causality } \\
LGCF does not Granger Cause LPLR & 1.015 & 0.376 & Reject & \\
\hline LPLR does not Granger Cause LGDS & 0.588 & 0.562 & Reject & \multirow{2}{*}{ No Causality } \\
LGDS does not Granger Cause LPLR & 0.175 & 0.840 & Reject & \\
\hline
\end{tabular}

Source: Author's computations

Note: The test of significance is based on $5 \%$ level

The Granger causality tests conducted shows a feedback relationship between LGDP and LGDF in Nigeria at the $5 \%$ level of significance. This means that both variables have a causal relationship between them. A unidirectional causal relationship was found between LGDS and LGDP. Whereas, LGDP granger causes LGDS at the $1 \%$ significance level, there is no evidence to reject the null hypothesis that LGDS does not granger cause LGDP in Nigeria. Causality therefore flows from LGDP to LGDS in Nigeria. No causal relationship was however found between LPLR, LGDS and LGCF in Nigeria as could be seen in Table 8 above.

\section{Summary, Policy implications of results and Recommendation}

The purpose of this study was to empirically investigate the long run and short run dynamic impact of interest rate and output on gross domestic savings and gross capital formation in Nigeria. The results as presented in the preceding section reveal that output significantly affect Gross Domestic Savings and Gross Capital Formation in Nigeria in both the short run and long run. This supports the findings of Jain and Baliyan (2014), Linus (2013) and Adelakun (2015). The short run dynamic behaviour of both domestic investment and savings in Nigeria has been found to be mainly directly explained by Gross Domestic Product in conformity to the findings of Bayai and Nyangara (2013). By implication the recession currently experienced has a capacity to undermine the acceleration principle of investment by first inhibiting savings in the economy. In terms of causality, a bidirectional relationship was also found to exist between GDP and GCF. However, causality flows from GDP to GDS in Nigeria. This is in line with the findings of Appienti et al (2016) and Epaphra (2014).

Gross Domestic Savings and Gross Capital Formation were found to be relatively irresponsive to interest rate in Nigeria, supporting the results of Nasir and Khalid, 2014. No significant relationship was found between Prime lending rate and Gross Capital formation in Nigeria in both short run and long run corroborating the results of Kudaisi (2013), Duruechi and Ojiegbe (2015). Although a slightly significant relationship was found between PLR and GDS in the long run, no significant relationship was established in the short run dynamic behaviour of GDS with respect to changes in interest rate. This confirms the research findings of Ogbokor and Samahiya (2014). The results therefore suggest that the short run 
dynamic qualities of GCF and GDS are not explained by interest rates in Nigeria. This implies that in the short run contractionary monetary policy may not affect investments and ultimately outputs in the economy via interest rates after-all. The current recession may not be worsened by a contractionary monetary policy since the policy target is not affected by the proximate target adequately via the intermediate target (interest rate). Inflation was found to significantly affect GCF negatively in both long run and short run which was expected. However, in relation to GDS, though negative as expected in the short run, there appears not to be a significant relationship. A significant positive relationship was found to exist in the long run between inflation and GDS. This may be caused by the aversion for spending during periods of inflation in Nigeria.

Based on the empirical results, it is recommended that to enhance investment in a period of economic downturn in Nigeria, aggregate demand should be boosted to enhance output through vigorous pursuit of fiscal policy while implementing contractionary monetary policy to address inflationary pressures created by the increase in demand. Gross Domestic Savings will improve and Gross Capital Formation will be sustained thereby. A comparative analysis of the relative importance of both fiscal and monetary policy in influencing savings and investments in addressing the fundamental challenges of recession in Nigeria is therefore recommended for future research.

\section{References}

Acha, I. A. and Acha, C. K. (2011). 'Interest rates in Nigeria: An Analytical Perspective', Research Journal of Finance and Accounting, vol. 2, no. 3, pp. 71-81.

Acosta, P. and Loza, A. (2015). 'Short and Long run determination of private investment in Argentina', Journal of Applied Economics, vol. 8, no. 2, pp. $389-406$.

Adelakun, J. O. (2015). 'An investigation of the determinants of savings and investment in Nigeria', International Economic and Business Journal, vol. 1, no. 2, pp. 1-16.

Appienti, W. A., Ofori, D., Damptey, A. O. and Kusi, A. (2016). Key determinants of investment in Ghana: Cointegration and Causality analysis, European Journal of Business, Economics and Accounting, vol. 4, no. 5, pp. $41-49$.

Anyanwu, J.C. (1993). Monetary Economics: Theory, Policy and Institutions. Onitsha: Hybrid Publishers Ltd.

Bader, M. and Malawi, A.I. (2010). 'The Impact of interest rate on investment in Jordan: A Cointegration Analysis', Journal of King Abdul Aziz University: Economics and Administration. vol. 24, no. 1, pp. 199-209.

Bayai, I. and Nyangara, D. (2013). 'An analysis of determinants of investment in Zinbabwe for the period 2009 - 2011'. International Journal of Economics and Management, vol. 2, no. 6, pp. $11-42$.

Duruechi, H. A. and Ojiegbe, N. J. (2015). 'Determinants of investments in the Nigerian economy: An empirical approach (1990 - 2013)', International Journal of Financial Research, vol. 6, no. 4, pp. $217-227$.

Epaphra, M. (2014). 'Empirical investigation of the determinants of Tanzania's national savings', Journal of Economics and Development Studies, vol. 2, no. 4, pp. $223-241$.

Iyoha M.A. (2007). Intermediate Macro-Economics. Benin City: Mindex Publishers.

lyoha, M. A., Oyefusi, S. A. and Oriakhi, D.E. (2003). An Introduction to Modern Microeconomics, Benin City: Mindex Publishing.

Jain, G. and Baliyan, M. (2014). 'Determinants of savings and investment in India', SSARC International Journal of Geo Science and Geo Informatics, vol. 1, no. 1, pp. 1-13.

Keynes, J. M. (1936). The General Theory of Employment, Interest and Money. London: Macmillan.

Kudaisi, B. V. (2013). 'Savings and its determinants in West Africa countries', Journal of Economics and Sustainable Development', vol. 4, no. 18, pp. $107-119$. 
Larsen, J. E. (2004). 'The impact of loan rates on direct real estate investment holding period return', Financial Services Review, vol.13, pp. 111-121.

Linus, U. D. (2013). Determinants of investment in Nigeria (1985 - 2011). A dissertation submitted to the department of economics, Caritas University, Enugu State in partial fulfilment of the requirements for the award of Bachelor of Sciences degree in economics.

McKinnon, R. I. (1973). Money and capital in economic development, Washington, DC: Brookings Institution.

Nasir, S. and Khalid, M. (2014). 'Saving - investment Behaviour in Pakistan: An empirical investigation. The Pakistan development review', vol. 43, no. 4, pp. 665-682.

Ogbokor, C. A. and Samahiya, O. M. (2014). 'A time series analysis of the determinants of savings in Namibia. Journal of economics and sustainable development', vol. 5, no. 8, pp. $52-63$.

Okere, P. A. and Ndugbu, M. (2015). Macroeconomic variables and savings mobilisation in Nigeria. International Journal for Innovation, Education and Research, vol. 3, no. 1, pp. 105 $-116$.

Olayemi, S. O. and Michael, J. O. (2013). 'Real interest rate and savings mobilisation in Nigeria. International Journal of Development and Economic Sustainability, vol. 1, no. 2, pp. 28-40.

Shaw, E. (1973). Financial Deepening in Economic Development, New York: Oxford University Press.

Uche, S. K. (2012). The impact of interest rates on savings and investment in Nigeria. Project presented to the department of Banking and Finance, Faculty of Business Administration, Enugu, in partial fulfillment of the requirements for the award of Masters in Business Administration degree in Banking and Finance.

Udude, C. C. (2015). Impact of interest rate on savings on the Nigeria's economy (1981 2013). Journal of Policy and Development Studies, vol. 9, no. 3, pp. $73-82$.

World Development Indicators (2016). World Development Indicators. Available at: http://data.worldbank.org/products/wdi. [15 December 2016]

\section{Bio-note}

Abusomwan Success is a lecturer at the University of Benin, Benin City, Nigeria. He teaches financial and monetary economics at the university and conduct researches in those fields of economics

Ezebuihe Jessy is a researcher at the University of Nigeria, Nsukka, Nigeria. 